\title{
FERROSPECTRAL SORBED ON DEAE SEPHADEX A-25 FOR THE SOLID PHASE SPECTROPHOTOMETRIC DETERMINATION OF IRON AND COBALT BY BATCH AND CONTINUOUS FLOW MODES
}

\author{
M. INES TORAL *I, GRISEL SANCHEZI, PRISCILLA FERNANDEZ', PATRICIA PIZARRO', \\ VIVIANA MONCADA ${ }^{1}$, JORGE RIVAS ${ }^{1,2}$, PABLO RICHTER ${ }^{2}$ \\ 'Department of Chemistry, Faculty of Sciences, University of Chile, P.O. Box 653, Santiago, Chile. \\ ${ }^{2}$ Department of Inorganic and Analytic Chemistry, Faculty of Chemical and Pharmaceutical Sciences, University of Chile, P.O. Box 223.
}

(Received: September 27, 2010 - Accepted: May 25, 2011)

\begin{abstract}
In this work, Ferrospectral;3-(2-pyridyl)-5,6-bis(4-phenylsulfonic acid)-1,2,4-triazine (FST) sorbed on DEAE Sephadex A-25 is used as solid phase for spectrophotometric determination of iron and cobalt by batch and continuos flow modes. In batch simultaneous determination, the second derivative at 536.0 and $601.4 \mathrm{~nm}$ were used for iron and cobalt determination, respectively. In this modality, the detection limits $(3 \sigma$ criterion), for iron and cobalt were $1.3,9.1, \mu \mathrm{g}$ $\mathrm{L}^{-1}$ and the determination ranges were: 4.3 to 220 and 30.3 to $800 \mu \mathrm{g} \mathrm{L}{ }^{-1}$. The method by FIA mode was carried out by stopped flow and then the analytical signal was evaluated by second derivative at 560.9 and $482.3 \mathrm{~nm}$ for iron and cobalt determination; respectively. In FIA modality, the detection limits for iron and cobalt were $6.4,31 \mu \mathrm{g} \mathrm{L}^{-1}$, and the determination ranges 21 to 200 and 106 to $1000 \mu \mathrm{g} \mathrm{L}-1$ iron and cobalt, respectively. In both modalities the repeatability for iron and cobalt were $<4 \%$ and the recovery was near to $100 \%$. These methods were applied successfully in drinking water and soil samples.
\end{abstract}

Keywords: Solid phase spectrometry, Fe (II), Co (II), 3-(2-pyridyl)-5,6-bis(4-phenylsulfonic acid)-1,2,4-triazine-DEAE Sephadex A-25, Batch and continuous determination.

\section{INTRODUCTION}

At this time, there are various methodologies for the metals determination in different matrices such as food samples ${ }^{1,2}$ environment ${ }^{3,4}$, biological ${ }^{5,6,7}$, among others. However, very few methods has been reported for simultaneous determination of iron and cobalt by spectrophotometry, since the absorption bands of both analytes are highly overlapped

Most of the methodologies are carried out with highly sophisticated instrument that requires a thorough sample preparation, previous to measuring the analytical signal.

This situation has been described in numerous papers in which various metals are determined by inductively coupled plasma (ICP) with mass spectroscopy detector (MS) or optical emission detector $(\mathrm{OES})^{1,5,8}$ or by flame atomic absorption spectroscopy (FAAS) with graphite furnace (GF-AAS) $)^{9,10}$ besides using different electrochemical techniques ${ }^{11,12}$, but the difficulty of these techniques are its high costs.

In order to decrease the limits of detection have been developed and implemented different methodologies, in which the first stage include an extraction of analytes using external energy ${ }^{13}$, a sorbent material ${ }^{9}$, or the presence of some reagent to react chemically with the analyte ${ }^{8}$.

Many methods use the formation of colored complexes to become more selective and sensitive. A spectrophometric method for the determination of iron, cobalt and nickel using 1 - (2-pyridylazo)-2-naphtol (PAN) has been proposed ${ }^{14}$. The iron, cobalt and nickel determination using 2,2'-dipyridylketone-2pyridylhydrazone and isoquinoline-3-aldehyde-2-pyridylhydrazone has been proposed ${ }^{15}$.

Other methods based in the formation of complexes for determination of iron and cobalt also has been described ${ }^{16,17}$. However these methods have low sensitivity to resolve actual problems, because in many cases, it is necessary to achieve very low detection limits, especially in those analytes that have a high toxicity.

In many cases, the use of sensors increases the sensitivity and selectivity in the method ${ }^{18,19,20}$. This paper proposes the development of a sensor formed by an anion-exchange resin, which is paired with 3 - (2-pyridyl) -5,6-bis (4-phenylsulfonic acid)-1,2,4- triazine, Ferrospectral (FST), a chelating agent, which bind $\mathrm{Fe}$ (II) and $\mathrm{Co}$ (II) in presence of hydroxylamine at $\mathrm{pH} 4.75$.

In order to optimize the time of analysis and strengthen the proposed method intends to work in the use of continuous systems, which reduces time and cost analysis. The literature shows that there are methods for the determination of iron by this route ${ }^{21}$, but does not include the determination of cobalt and other metals, in this way suggests the development of an analytical method, accurate, sensitive and selective for the determination of Fe (II) and Co (II) by forming complexes with a resin-FST sensor and its evaluation by second order derivative spectrophotometry, comparing strategies working both in static (batch system) or continuous system (flow injection analysis, FIA) and analyzing the study variables using a multivariate design, giving an understanding of both the chemical and statistical significance of chemical and spectral variables of the method. Beside in this work a Tygon cell is introduced, what allows to diminish considerably the cost of the method in relation to the use of flow cell.

This method is applied to soil samples, but the developed method also allows the determination of analytes in any aqueous sample, or to be treated so that the analytes are in aqueous medium.

\section{EXPERIMENTAL}

Instruments and Apparatus

A Shimadzu (Shimadzu Co, Kyoto, Japan) spectrophotometer with 1 and $10 \mathrm{~mm}$ glass cells were used for measurement of the absorbance and derivative absorption spectra in solid phase and aqueous solution, respectively. For all the tested solutions, the spectra were recorded over a range of 350 to 800 $\mathrm{nm}$ versus the corresponding reagent blanks by using slit width values and sampling intervals of 2.0 and $0.2 \mathrm{~nm}$, respectively. A scan speed of $480 \mathrm{~nm}$ $\mathrm{min}^{-1}$ was also used. The derivative spectra were obtained using a software Shimadzu kit version 3.7 (P/N 206-60570-04).

All solid samples were weighed to within $\pm 0.01 \mathrm{mg}$ by using a Sartorius R 200D analytical balance. An Orion Digital Research Ion-Analyzer 701 with glass and saturated calomel electrodes was used for $\mathrm{pH}$ determinations. A magnetic stirrer HI 190 M Hanna instrument for the preconcentration step was also used.

A High performance microwave digestion unit, model MLS-1200 mega was used for digestion of soils samples.

The optimizations of variables by experimental full factorial design were carried out by means of software Statgraphics Plus software version 5.1.

Chemicals and Reagents

All reagents were of analytical grade and the solutions were prepared with high-purity water from a NANO pure Barnstead ultrapure water system device.

Commercial standard solutions of $1000 \mathrm{mg} \mathrm{L}^{-1} \mathrm{Fe}$ (II) and Co (II) were purchased from Merck ${ }^{\circledR}$ (Darmstadt, Germany). The FST was also purchased from $\operatorname{Merck}^{\circledR}$ (Darmstadt,Germany). The $\mathrm{pH} 4.75$ was adjusted with a $\mathrm{CH}_{3} \mathrm{COOH} 0.1 \mathrm{~mol} \mathrm{~L}^{-1} / \mathrm{CH}_{3} \mathrm{OONa} 0.1 \mathrm{~mol} \mathrm{~L}^{-1}$ buffer solution $\left(\mathrm{HAc} / \mathrm{Na}^{+} \mathrm{Ac}, \mathrm{pH}\right.$ 
4.75). DEAE Sephadex A-25 anionic exchanger was purchased from Aldrich ${ }^{\circledR}$ (St. Louis, USA).

In the validation of the method a High Purity Control Standards (QCS-19) ${ }^{\circledR}$ was used. The content of this standard in $100 \mathrm{mg} \mathrm{L}^{-1}$ is: $\mathrm{Sb}, \mathrm{As}, \mathrm{Be}, \mathrm{Cd}, \mathrm{Ca}$, $\mathrm{Cr}, \mathrm{Co}, \mathrm{Cu}, \mathrm{Fe}, \mathrm{Pb}, \mathrm{Mg}, \mathrm{Mn}, \mathrm{Mo}, \mathrm{Se}, \mathrm{Tl}, \mathrm{Ti}, \mathrm{V}, \mathrm{Zn}, \mathrm{Ni}$ and trace of $\mathrm{HF}$ in $4 \%$ $\mathrm{HNO}_{3} \mathrm{v} / \mathrm{v}$.

Procedure to form the sensor FST- DEAE Sephadex A-25

In a glass baker of $400 \mathrm{~mL} 100 \mathrm{~mL}$ of FST $5 \times 10^{-3} \mathrm{~mol} \mathrm{~L}^{-1}$ and $2 \mathrm{~g}$ of DEAE Sephadex A-25 were added. The mixture was stirring for $1 \mathrm{~h}$ and then filtered. The solid phase was isolated and dried at $100{ }^{\circ} \mathrm{C}$ for $2 \mathrm{~h}$.

Procedure for Preconcentration and Determination in batch of Metal Ions The preparation of the samples were carried out in a final volume of 100 $\mathrm{mL}$ aqueous solution and were added between 10 and $140 \mu \mathrm{L}$ of $\mathrm{Fe}$ (II) and 50 and $500 \mu \mathrm{L}$ of Co (II), both metallic ions concentration were of $100 \mathrm{mg} \mathrm{L}^{-1}$. Then were added $10 \mathrm{~mL}$ of $\mathrm{HAc} / \mathrm{Na}^{+} \mathrm{Ac}^{-}(\mathrm{pH} 4.75)$ buffer solution and $1 \mathrm{~mL}$ of hydroxylamine $10 \%$. In each solution $80 \mathrm{mg}$ of FST- DEAE Sephadex A-25 was added and stirred for 30 minutes. Parallel, in the same conditions a reagent blank without the analytes was prepared. The solid phase and reagents blank were packed in quartz cells of $1 \mathrm{~mm}$ optical path and the absorption spectra vs. reagents blank were carried out on wavelengths range between 350 to $800 \mathrm{~nm}$. The second order derivative was obtained using a smoothing factor of 40,000 and a scale factor of 10,000 .

\section{Manifold and procedure}

The FIA manifold is shown in Figure 1. With an injection valve IV3, $\mathrm{HCl}$ $2 \mathrm{~mol} \mathrm{~L}^{-1}$ was first inserted in the carrier in order to obtain the base line. Sample (IV1) and ligand (IV2) were injected simultaneously in a carrier solution prepared daily containing buffer and hydroxylamine $(1 / 1 \mathrm{v} / \mathrm{v})$ at a flow rate of $1.0 \mathrm{~mL} \mathrm{~min}^{-1}$. The iron of the sample was reduced in the mixing coil $\mathrm{R}(60 \mathrm{~cm} \mathrm{x}$ $0.5 \mathrm{~mm}$ i.d.) and both analytes also reacted with the ligand in R. The complexes were transported to the detector and the signal was monitorized at $550 \mathrm{~nm}$. A Tygon tube of $2 \mathrm{~cm} \times 1.5 \mathrm{~mm}$ i.d. that contains DEAE Sephadex A-25 resin was used as flow through sensor which retains complexes of $\mathrm{Fe}$ (II) and Co (II). When the signal reached the maximum height the flow was stopped. The absorption spectrum was scanned between 400 and $800 \mathrm{~nm}$ and obtained the second derivative spectrum, using a smoothing factor of 40,000 and a scale factor of 10,000 . Subsequently the pump was switched and the eluent $(\mathrm{HCl} 2$ mol L${ }^{-1}$ ) was injected (IV3) to eliminate the complexes of the resin and then other sample can be injected.

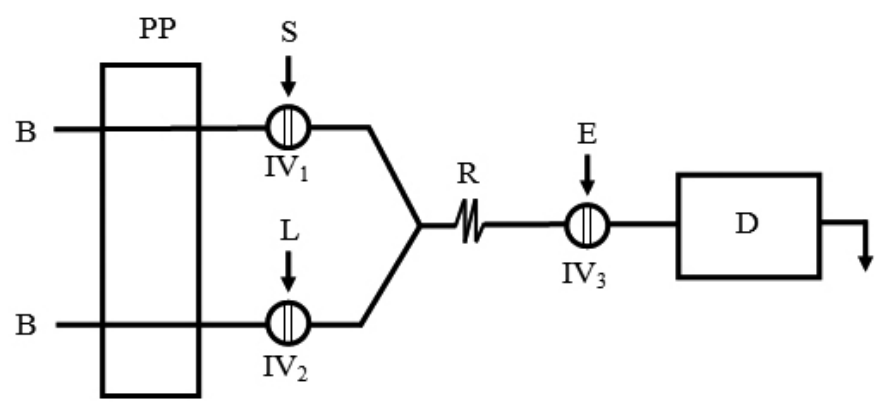

Figure 1. Manifold for Co (II) and Fe (II) determination. B, Buffer; PP, peristaltic pump, S, sample; L, ligand; IV, injection valve, R, reactor coil; E, eluent; $\mathrm{D}$, detector.

Procedure for digestion of soils samples

In the samples preparation of soil for determination of $\mathrm{Fe}$ (II) and Co (II) two soils were used, sampled in the Central Zone of Chile. An aliquot of approximately $200 \mathrm{mg}$ of sample of each soil was accurately weighted and transferred to digestion funnel. Aliquots of $4 \mathrm{~mL}$ concentrated $\mathrm{HNO}_{3}$ (Merck, Darmstadt, Germany), $4 \mathrm{~mL}$ concentrated HF (Merck, Darmstadt, Germany) and $4 \mathrm{~mL} \mathrm{H} \mathrm{O}_{2} 30 \%$ (Merck, Darmstadt, Germany) were added. For microwave digestion procedure the program used was: $5 \mathrm{~min}$ to $250 \mathrm{~W}, 5 \mathrm{~min}$ to $400 \mathrm{~W}, 10$ $\mathrm{min}$ to $500 \mathrm{~W}$ and $1 \mathrm{~min}$ to ventilation. Finally, the samples were carried out to dryness and reconstituted with $10 \mathrm{~mL}$ of water ${ }^{22}$.

\section{RESULTS AND DISCUSSION}

The Co (II) and Fe (II) metallic ions react with FST giving color complexes, these complexes are formed with $-\mathrm{N}$ : group. On the other hand, FST contains sulfonic groups, which can be retained in anionic exchange, DEAE Sephadex A-25, which could be used as solid phase and/or sensor. In first time FST was previously retained on the resin to obtain a solid phase. In an aqueous phase, containing independently $\mathrm{Fe}$ (II) and $\mathrm{Co}$ (II) in presence of hydroxylamine and buffer $\mathrm{pH} 4.75$, was added FST-resin and stirred the solid phase. The spectra of metallic complexes retained on the sensor scanned vs. FST-DEAE Sephadex A25 is shown in Figure 2, as can be seen each metallic ion presents a well defined bands, this means that $\mathrm{Fe}$ (II) and Co (II) are retained in the solid phase, this fact can be attributed to formation of complexes with the $-\mathrm{N}$ :. These results are indicative of the possibility to develop an analytical method in batch mode. Further, it was assessed the reversibility of the system, to the solid phases contained each metallic cation. It was added $\mathrm{HCl} 1.0 \mathrm{~mol} \mathrm{~L}^{-1}$ as eluting agent and only the cations were rapidly and quantitatively liberated. This fact allows using this solid phase as sensor in FIA or in continuous systems.

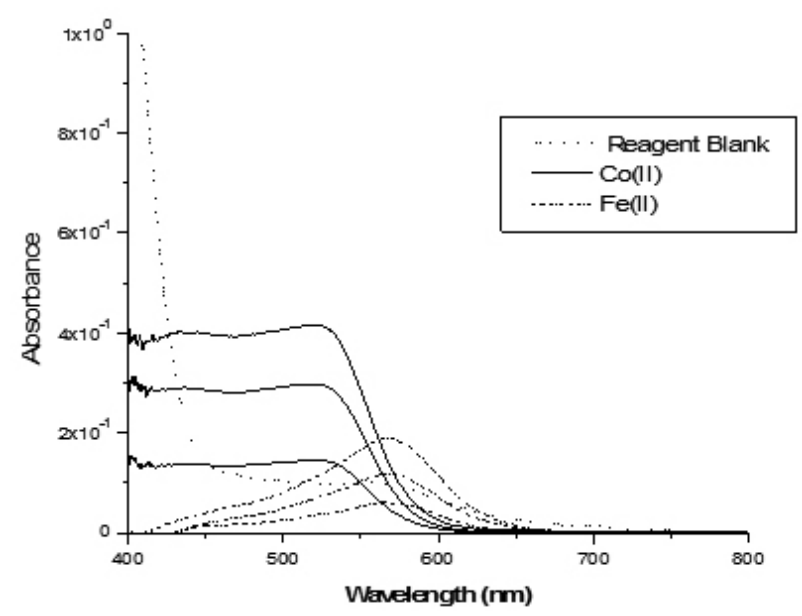

Figure 2. Zero order spectra of the complexes retained on FST-DEAE Sephadex A-25, against reagent blank. Concentration: Co (II) between $1.7 \times 10^{-6}$ and $5.1 \times 10^{-6} \mathrm{~mol} \mathrm{~L}^{-1}, \mathrm{Fe}(\mathrm{II})$ between $1.8 \times 10^{-7}$ and $5.4 \times 10^{-7} \mathrm{~mol} \mathrm{~L}^{-1}$.

\section{Adsorption isotherm}

For the determination of the sorption capacity of the solid phase FSTDEAE Sephadex A- 25, the amount of sorbed Co (II) and Fe (II) were studied independently as a function of each concentration (Figure 3 ). The model proposed by Langmuir was analyzed. The linearization of Langmuir isotherm can be obtained by plotting Ce/q as a function of Ce.

The slope of the plot yields the maximum capacity (qm) whereas its linear coefficient represents the Langmuir constant $(\mathrm{K})$. The correlation coefficients of the linear equation obtained in this study were 0.999 . An analysis of the sorption behavior for Langmuir model reveals that equation give up a good fit. Thus, the adsorption isotherms of Co (II) and Fe (II) are according to the Langmuir equation (Figure $3 \mathrm{~b}$ ) and the graphical treatments of the data give as results $0.076 \mathrm{mg}$ and $0.049 \mathrm{mg}$ of Co (II) and Fe (II) per gram of FST DEAE Sephadex A-25 as maximum saturation capacity and equilibrium binding constants were; $\mathrm{K} 5.1 \times 10^{4}$ and $5.5 \times 10^{4} \mathrm{~mol}^{-1} \mathrm{~L}$, for Co (II) and $\mathrm{Fe}$ (II), respectively. The Langmuir treatment demonstrated that the surface is nearly fully covered with monomolecular layer of Co (II) and Fe (II) at high concentrations. In high concentrations adsorption does not increase linearly. The main sorption sites of the FST-DEAE Sephadex A-25 were the -N: groups forming a solid phase chelates. 

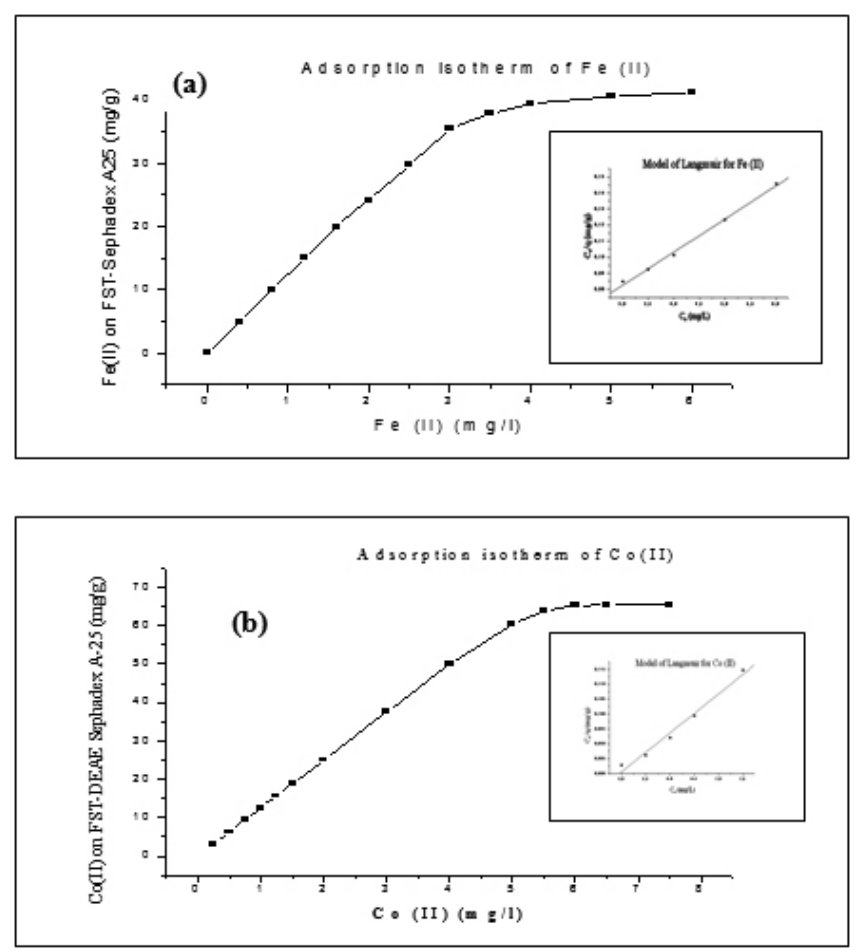

Figure 3. Adsorption isotherms of FST-DEAE Sephadex A-25 for Co(II) and Fe (II). $80 \mathrm{mg}$ of FST-DEAE Sephadex A-25, $2 \mathrm{~mL}$ hydroxylamine, $10 \mathrm{~mL}$ of buffer HAc $0.1 \mathrm{~mol} \mathrm{~L}^{-1} / \mathrm{NaAc} 0.1 \mathrm{~mol} \mathrm{~L}^{-1}$. (a) Co (II) at $\lambda=500 \mathrm{~nm}$ and (b) $\mathrm{Fe}$ (II) at $\lambda=561.5 \mathrm{~nm}$.

Experimental factorial designs.

The traditional way of studying the influence of several variables on a response is the univariable (one variable at a time) method. However, this classical method involves a large number of independent experiments and some important conclusions on the interaction among variables may be $\operatorname{misse}^{23}$. An efficient way to overcome these drawbacks is to use the experimental factorial design methodology, which is a collection of statistical and mathematical techniques useful for studying, improving and optimizing the development of analytical method ${ }^{24}$. The factorial design with two-level $\left(2^{\mathrm{k}}\right)$ is the largely popular, where $\mathrm{k}$ is the number of variables, because it is possible to obtain information about the significance of each variables and their interactions. Two-level factorial designs have many advantages in analytical procedures and the total number of experiments in factorial design is much lower compared to the univariable approach. In order to determine the behavior of the response variable on the region of interest a mathematical model must be used ${ }^{24}$.

In this work for the simultaneous determination in batch of $\mathrm{Fe}$ (II) and $\mathrm{Co}$ (II), the optimization of chemical and preconcentration variables were realized independently for each metallic ion. For the chemical variable an experimental full factorial design $2^{2}$ was used with one central point and in triplicate $(15$ experiments), where it was optimized, $\mathrm{pH}$ and buffer concentration in the intervals 6-4 and $0.5-0.05 \mathrm{~mol} \mathrm{~L}^{-1}$, respectively. For the optimization of preconcentration the same design was used with two central points and in quadruplicate. The variable optimized were mass of solid phase and stirring time used as limit values $120-80 \mathrm{mg}$ and $30-10 \mathrm{~min}$, respectively. The Figure 4 shows the Pareto graphics for the chemical optimization of the determination of Fe (II) and Co (II) and Figure 5 presents the graphics that correspond to optimization of preconcentration step.

\section{Standarized Pareto Chart for Fe (II)}

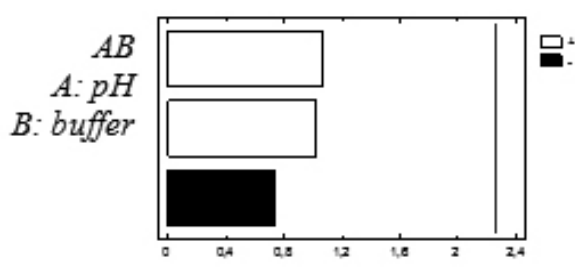

Standardized effect

\section{Standarized Pareto Chart for Co (II)}

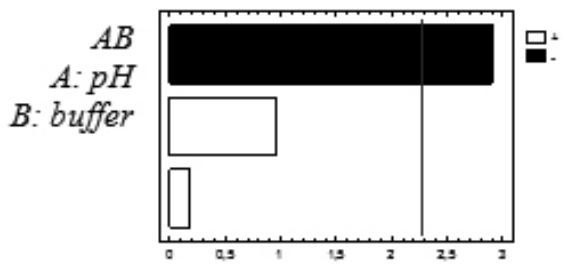

\section{Standardized effect}

Figure 4. Pareto graphics for Fe (II) and Co (II) for optimization step of chemical variables.

It was found that the concentration of $\mathrm{HAc} / \mathrm{Na}^{+} \mathrm{Ac}^{-}$buffer is only significant in the determination of $\mathrm{Co}$ (II), this fact can be attributed to that solid phase could to retain to $\mathrm{Ac}^{-}$ion of buffer. On the range studied, the $\mathrm{pH}$ is not significant for both analytes. Taking into account the graphics area, that the buffer volume is constant and the simultaneous determination of iron and cobalt will be carried out, was selected a concentration $0.1 \mathrm{~mol} \mathrm{~L}^{-1}(\mathrm{pH}=4.75)$, in order to increase the buffer capacity.

\section{Standarized Pareto Chart for Fe (II)}

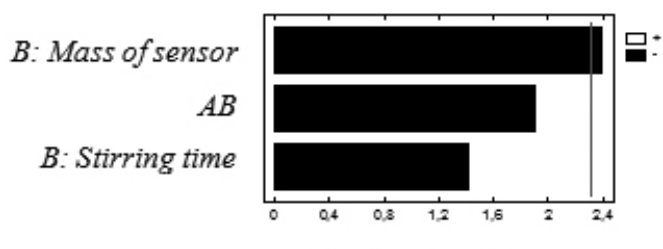

Standardized effect

\section{Standarized Pareto Chart for Co (II)}

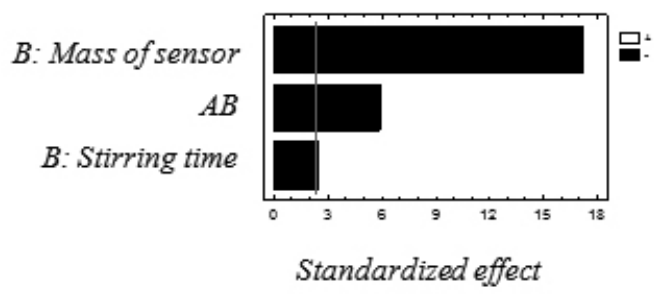

Figure 5. Pareto graphics for Fe (II) and Co (II) for optimization step of preconcentration variables. 
In the preconcentration optimization was found that mass of sensor FST-resin is significant for Fe (II) and Co (II) determination because the preconcentration is favoured when the amount of solid phase decrease. On the other hand, the amount of solid phase and stirring time interaction is slightly significant for Co (II), because the formation of the complexes are rapid, for this reason it is possible to establish that kinetic effect are not present. According to these results, the optimal stirring time is $30 \mathrm{~min}$, and the optimal amount of sensor is $80 \mathrm{mg}$ for both analytes.

\section{Selection of spectral variables}

Derivative order and analytical wavelength

In this work the digital derivative spectrophotometry technique is used, which is based on mathematic computational model proposed by Savitzky and Golay ${ }^{25}$. To optimize the derivative order, the first to the fourth derivative spectra of the respective complexes retained in solid phase were recorded. In Figure 6 are shown the first and second derivative, higher derivative orders were discarded because the sensibilities decrease and the noise is also increased. Derivative spectrophotometry ${ }^{26,27}$ is widely used and effective in systems where there are overlapping signals. Comparing these spectra derivative, the first derivative presents higher sensitivities that the second, but the first derivatives only present a zone characteristic for the Co (II) determination. The second derivatives for the Co (II) determination present zero crossing at 493 and 556 $\mathrm{nm}$; further in the range of 650 and $800 \mathrm{~nm}$, it does not present analytical signal. On the other hand, second derivatives for the $\mathrm{Fe}$ (II) determination also present zero crossing at 536.0 and $601.4 \mathrm{~nm}$, being possible this simultaneous determination. In this context, second derivative spectra were selected for the determination of Co (II) and Fe (II) in a sample by means of the zero crossing method at analytical wavelength of 601.4 and $556.0 \mathrm{~nm}$. These wavelengths were selected in order to favor the sensitivity of the method.
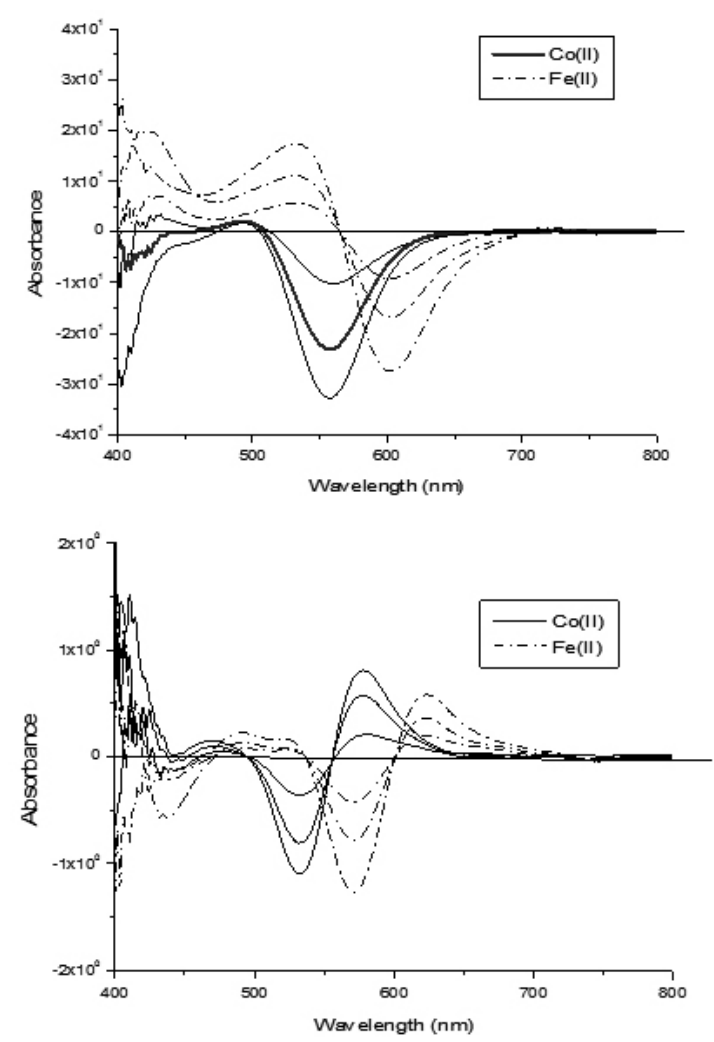

Figure 6. First and second derivative of the complexes retained on FTS-DEAE Sephadex A25, against reagent blank. (a) First derivative and (b) Second derivative. Concentration: Co (II) between $1.7 \times 10^{-6}$ and $5.1 \times 10^{-6} \mathrm{~mol}$ $\mathrm{L}^{-1}, \mathrm{Fe}$ (II) between $1.8 \times 10^{-7}$ and $5.4 \times 10^{-7} \mathrm{~mol} \mathrm{~L}^{-1}$.

Selection of the smoothing and scale factor.

For a $\Delta \lambda$ value of $450 \mathrm{~nm}$ the smoothing factor, corresponding to the number of points using in the derivation were the following: 5,000, 10,000, 20,000 and 40,000 . When the smoothing factor increases, the heights of derivative signal decreased, but the noise decreased more significantly, obtaining superior signal/noise ratios. A value of 40,000 was selected, because in these conditions the signal/noise ratio was favored and the sensibilities were underrated in order to decrease the error of the results. The derivative spectra, when this smoothing factor was used, distortion effects are not present. A value of 10,000 was selected as scale factor only to favor the lecture of the analytical signal, but not affect the sensitivity because the analytical signal and the standard deviation of the blank increase in the same proportion.

\section{Analytical Features}

The analytical features, for the batch determination of Co (II) at 556.0 $\mathrm{nm}$ and $\mathrm{Fe}$ (II) $601.4 \mathrm{~nm}$ were determined by second order derivative spectrophotometry using a smoothing factor of 40,000 and an amplification factor of 10,000 in $100 \mathrm{~mL}$ as total volume solution.

The equation for the Co (II) and Fe (II) determination obtained by the least squares method are shown in Table 2. The detection limits ( $3 \sigma$ criterion), quantification limits $(10 \sigma$ criterion), and determination ranges for Co (II) and $\mathrm{Fe}$ (II) are also shown in Table 1. The accuracy and the repeatability of the method were obtained using 10 samples containing $3.9 \times 10^{-7} \mathrm{~mol} \mathrm{~L}^{-1}$ and $2.3 \times 10^{-7} \mathrm{~mol} \mathrm{~L}^{-1}$ of $\mathrm{Co}$ (II) and $\mathrm{Fe}$ (II), respectively. The recoveries and as relative standard deviations, are also included in Table 1. Mixtures of $\mathrm{Fe}$ (II) and Co (II) of different concentrations were carried out by the proposed method and the results are shown in Table 2.

\section{FIA determination}

Optimization of the FIA system

The FIA system was optimized by examining the influence of chemical and FIA variables by means of an experimental full factorial design. The chemical variables $\left(2^{2}\right.$ design) with two different levels of each variable were studied. For FST concentrations $\left(7.5 \times 10^{-4}-7.5 \times 10^{-3} \mathrm{~mol} \mathrm{~L}^{-1}\right)$ and $\mathrm{HCl}$ concentrations $\left(2-3 \mathrm{~mol} \mathrm{~L}^{-1}\right)$ were assessed. A FST of $7.5 \mathrm{x} 10^{-3} \mathrm{~mol} \mathrm{~L}^{-1}$ and $\mathrm{HCl} 2 \mathrm{~mol} \mathrm{~L}^{-1}$ were found to be providing the optimal results. The buffer concentration was scarcely influential. In the optimized of hydrodynamic flow variables $\left(2^{4} \mathrm{design}\right)$ were selected different values based on preliminary results in order preventing the effects of sensor contraction. The variables studied included the injected volumes $(V)$, mixing reactor length $(\mathrm{R}), \mathrm{V} 1(82-200 \mathrm{uL}) \mathrm{V} 2(83-300 \mathrm{uL}) \mathrm{V} 3$ $(82-200 \mathrm{uL})$ and $\mathrm{R}(46-76 \mathrm{~cm})$ were study and it were found to be optimal 200 , 300,100 and $76 \mathrm{~cm}$, respectively.

In these conditions the signals of $\mathrm{Fe}$ (II) and $\mathrm{Co}$ (II) at concentration between 50 to $200 \mathrm{ng} \mathrm{mL}^{-1}$ were obtained. The fiagramms obtained are shown in Figure 7.
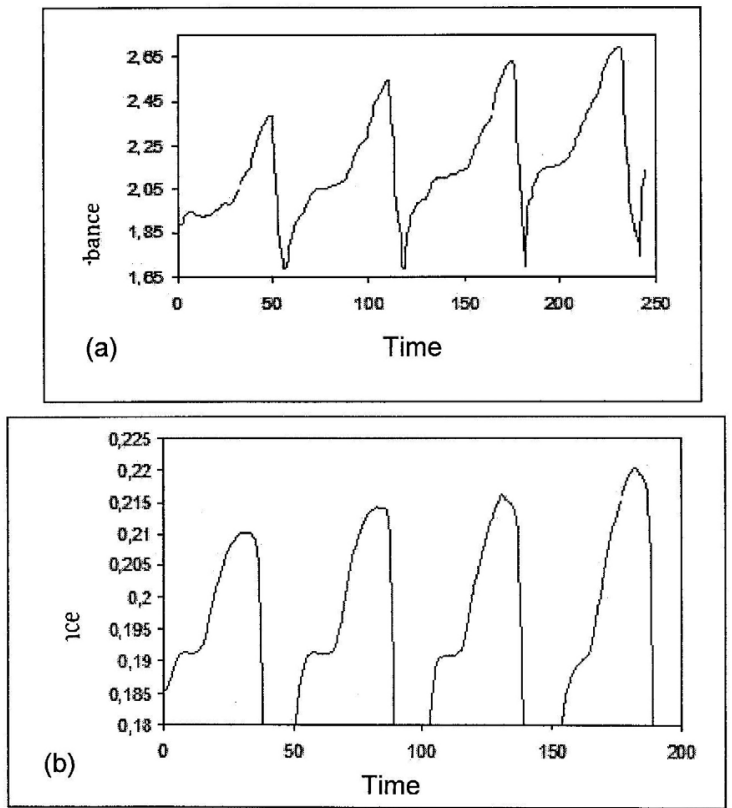

Figure 7. Fiagramms of (a) $\mathrm{Fe}$ (II) to different concentrations (50 $\mathrm{ng} \mathrm{mL}^{-1}$, $100 \mathrm{ng} \mathrm{mL}^{-1}, 150 \mathrm{ng} \mathrm{mL}^{-1}, 200 \mathrm{ng} \mathrm{mL}^{-1}$ ) (b) spectrum of Co (II) to different concentrations ( $\left.50 \mathrm{ng} \mathrm{mL}^{-1}, 100 \mathrm{ng} \mathrm{mL}^{-1}, 150 \mathrm{ng} \mathrm{mL}^{-1}, 200 \mathrm{ng} \mathrm{mL}^{-1}\right)$. 
The batch method above described for the simultaneous determination of Fe (II) and Co (II), was also implemented by FIA system. According to the procedure described in experimental, different solutions of analytes were injected into manifold. When the FIA signal reached the maximum absorbance, the flow was stopped and the signals acquire a constant value because the reaction was completed. In first time, it was injected each analyte individually and when the stability conditions were obtained the spectra were scanned and it was found that the band are overlapped, so that second derivative was obtained (Figure 8).

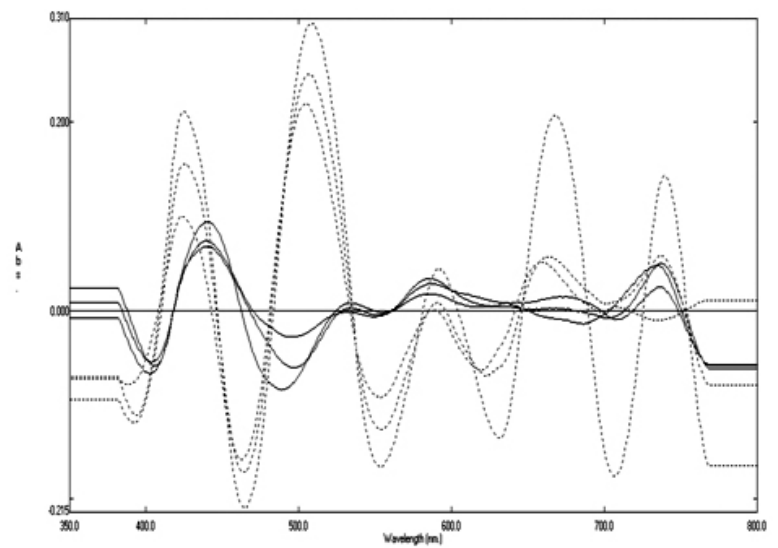

Figure 8. Second derivative spectra recorded of zero order spectra of samples recorded after stopped flow process. (

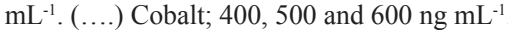

According to Figure 8, the second derivative of each complex shows characteristic points for the determination of both analytes. Iron was determined at $560.9 \mathrm{~nm}$ and cobalt at $482.3 \mathrm{~nm}$ corresponding to the zero crossing point of derivative spectra of cobalt and iron, respectively. In this condition, the second derivatives are similar with those obtained in batch.

\section{Features of proposed FIA method}

Under the optimized working conditions, a series of standards solution of Fe (II) between 40 to $200 \mathrm{ng} \mathrm{mL}^{-1}$ and of Co (II) 120 to $1000 \mathrm{ng} \mathrm{mL}^{-1}$ were injected independently into the manifold. The linear relations between peak height in DU and the concentration of the metallic ions and the analytical features are shown in Table 1. Mixtures of $\mathrm{Fe}$ (II) and Co (II) of different concentrations were injected and then under stopped flow conditions spectra and their derivatives were obtained. The results are summarized in Table 2.

Table 1 Analytical features for batch and FIA determination.

\begin{tabular}{|l|c|c|c|c|}
\hline \multirow{2}{*}{$\begin{array}{c}\text { Analytical } \\
\text { parameters }\end{array}$} & \multicolumn{2}{|c|}{ Batch determination } & \multicolumn{2}{c|}{ FIA determination } \\
\cline { 2 - 5 } & Iron & Cobalt & Iron & Cobalt \\
\hline $\begin{array}{l}\text { Detection limit } \\
\left(\mu \mathrm{g} \mathrm{L}^{-1}\right)\end{array}$ & 1.3 & 9.1 & 6.4 & 31 \\
\hline $\begin{array}{l}\text { Determination } \\
\text { limit }\left(\mu \mathrm{g} \mathrm{L}^{-1}\right)\end{array}$ & 4.3 & 30.4 & 21 & 106 \\
\hline $\begin{array}{l}\text { Determination } \\
\text { range }\left(\mu \mathrm{g} \mathrm{L}^{-1}\right)\end{array}$ & $4.3-220$ & $30.3-800$ & $21-200$ & $106-1000$ \\
\hline $\begin{array}{l}\text { Repeatability } \\
(\mathrm{RSD}, \%)\end{array}$ & 3 & 2 & 3 & 4 \\
\hline $\begin{array}{l}\text { Regression lines } \\
=2.9 \times 10^{-2} \\
\mathrm{C}+0.05\end{array}$ & $\begin{array}{c}\mathrm{DU}=2.9 \times 10^{-3} \\
\mathrm{C}+0.005\end{array}$ & $\begin{array}{c}\mathrm{DU}= \\
2.8 \times 10^{-3} \\
\mathrm{C}-0.05\end{array}$ & $\begin{array}{c}2.9 \mathrm{xU} 10^{-4}+ \\
0.03\end{array}$ \\
\hline $\begin{array}{l}\text { Correlation } \\
\text { coefficient }\end{array}$ & 0.994 & 0.998 & 0.994 & 0.997 \\
\hline
\end{tabular}

Where DU, in derivative units, and C correspond to analyte concentration in $\mathrm{ng} \mathrm{mL}^{-1}$.
Table 2 Analytical features for batch and FIA determination.

\begin{tabular}{|c|c|c|c|c|}
\hline \multirow{2}{*}{$\begin{array}{c}\text { Fe(II)/Co(II) } \\
\text { ratio }\end{array}$} & \multicolumn{4}{|c|}{$\begin{array}{c}\text { Recovery* } \\
(\% \pm \text { SD) }\end{array}$} \\
\hline \multirow{2}{*}{} & Batch determination & FIA determination \\
\cline { 2 - 5 } & Iron & Cobalt & Iron & Cobalt \\
\hline $60 / 50$ & $103.7 \pm 3$ & $100.0 \pm 1$ & $103.2 \pm 2$ & $\mathrm{D}$ \\
\hline $80 / 50$ & $104.6 \pm 4$ & $102.6 \pm 3$ & $103.5 \pm 3$ & $\mathrm{D}$ \\
\hline $110 / 50$ & $100.5 \pm 4$ & $103.6 \pm 3$ & $104.6 \pm 4$ & $\mathrm{D}$ \\
\hline $50 / 150$ & $101.4 \pm$ & $103.5 \pm 2$ & $103.2 \pm 4$ & $102.6 \pm 3$ \\
\hline $50 / 200$ & $99.8 \pm 0.2$ & $104.1 \pm 1$ & $104.6 \pm 3$ & $99.8 \pm 3$ \\
\hline $50 / 300$ & $96.6 \pm 3.4$ & $99.0 \pm 1$ & $104.6 \pm 3$ & $101.2 \pm 3$ \\
\hline
\end{tabular}

Study of interferents

The method provides high selectivity, because the alkali and alkaline earth metals, $\mathrm{Cr}$ (III), Pb (II), Se (IV), Mo (VI), Sb (III), As (III), Cd (II), Hg (II) and $\mathrm{Mn}$ (II) do not interfere tested to a maximum of $6 \mathrm{mg} \mathrm{L}^{-1}$. The presence $\mathrm{Cu}$ (II) $0.1 \mathrm{mg} \mathrm{L}^{-1}, \mathrm{Ni}$ (II) $1 \mathrm{mg} \mathrm{L}^{-1}$ and $\mathrm{Zn}$ and $\mathrm{Cd}$ (II) $6 \mathrm{mg} \mathrm{L}^{-1}$ alter the signal spectrum. This interference is due to the cations present in the sample competing for the active centers on solid phase.

In order to eliminate the copper interference in the analytical measurements studies were carried out in order to mask the presence of this interference. This was carried out using sodium citrate dihydrate as masking agent, obtaining an optimum amount of $2.5 \mathrm{~g}$ of citrate solution that does not affect the shape or the height of the spectral signals of a mixture of Fe (II)-FST and Co (II)FST retained in solid phase. It is necessary to highlight that the experimental conditions were kept constant according to experimental procedure. However, it was necessary to control the $\mathrm{pH}$ because the citrate increases its value. Under these conditions increased the tolerance limit of $\mathrm{Cu}$ (II) to $2 \mathrm{mg} \mathrm{L}^{-1}$.

\section{Validation and application}

The methods were validated using a High Purity Quality Control Standards QCS-19 ${ }^{\circledR}$. An aliquot $0.1 \mathrm{~mL}$ of this sample was measured and diluted to a 100 $\mathrm{mL}$ solution. The recoveries of Co (II) and Fe (II) were between 97 and $103 \%$. The RSD was $<2 \%$. The proposed methods were applied directly to drinking water; these samples were obtained of the Laboratory of Analytical Chemistry of Faculty of Science, University of Chile. When the batch method was applied $35 \pm 0.02 \mathrm{ng} \mathrm{mL}^{-1}$ for iron were found and cobalt was only detected. Similar results for iron determination by FIA mode were found, but cobalt does not was detected for this proposed method. The proposed methods were also applied in two soils sampled in the Central Zone of Chile. For the soil 1 was found $0.37 \pm 0.01$ and $0.06 \pm 0.02 \mathrm{mg} \mathrm{g}^{-1}$ for iron and cobalt, respectively. For the soil 2 was found $0.38 \pm 0.05$ and $0.073 \pm 0.01 \mathrm{mg} \mathrm{g}^{-1}$ for iron and cobalt, respectively.

\section{ACKNOWLEDGEMENTS}

The authors are grateful to the National Fund for Development of Sciences and Technology (FONDECYT), project 1070905 for the financial support and also to Valetta Blas by experimental work.

\section{REFERENCES}

1. Nardi, E.P., F. S. Evangelista, L. Tormen, T. D. Saint Pierre, A. J. Curtius, S. S. de Souza and F. Barbosa Jr. Food Chem. 112: 727-732. (2009)

2. Murakami M. and N. Ae. J. Hazard. Mater. 162: 1185 - 1192. (2009).

3. Soylak, M. and R. Sungur. J. Hazard. Mater. 146: 142 - 147. (2007).

4. Ghaedi, M., K. Niknam, A. Shokrollahi, E. Niknam, H. R. Rajabi and M. Soylak. J. Hazard. Mater. 155: 121 - 127. (2008). 
5. Suleiman, J. S., B. Hu, C. Huang and N. Zhang. J. Hazard. Mater. 157: 410 - 417. (2008)

6. Kazi, T. G., M. K. Jamali, M. B. Arain, H. I. Afridi, N. Jalbani, R. A. Sarfraz and R. Ansari. J. Hazard. Mater. 161: 1391 - 1398. (2009).

7. Aguerssif, N., M. Benamor, M. Kachbi and M. T. Draa. J. Trace. Elem. Med. Bio. 22: 175 - 182. (2008).

8. Bezerra, M. A., S. M. do Nascimento-Maêda, E. P. Oliveira, M. F. Batista de Carvalho and R. E. Santelli. Spectrochimica Acta Part B: Atom. Spectrosc. 62: 985 - 991. (2007).

9. Ghaedi, M., F. Ahmadi and A. Shokrollahi. J. Hazard. Mater. 142: $272-$ 278. (2007).

10. Tuzen, M. and M. Soylak. J. Hazard. Mater. 162: 724 - 729. (2009).

11. Laglera, L. M., G. Battaglia and C.M.G. van den Berg. Anal. Chim. Acta. 599: $58-66$. (2007).

12. Segura, R., M.I. Toral and V. Arancibia. Talanta 75: 973-977. (2008).

13. Rezić, I. Ultrason.Sonochem. 16: 63 - 69. (2009).

14. Zarei, K., M. Atabati and Z. Malekshabani. Anal. Chim. Acta. 556: 247 254. (2006)

15. DiTusa, M. R. and A. A. Schilt. Microchem. J. 32: 44 - 49. (1985)

16. Toral, M. I., P. Richter, L. Silva and A. Salinas. Microchem. J. 48: 221228. (1993)
17. Richter, P., M.I.Toral and P. Hernández. Anal. Lett. 26: 1013-1025. (1996).

18. Santos, W.J.R., P. R. Lima, A.A. Tanaka, S. M.C.N. Tanaka and L.T. Kubota. Food Chem. 113: 1206 - 1211. (2009).

19. Gąsiorowska, M., J. A. Soroka, M. J. Sawicka and E. K. Wróblewska. Talanta. 78: 49 - 51. (2009).

20. Sharma, R.K. and P. Pant. J. Hazard. Mater. 163: 295 - 301. (2009).

21. Teixeira, L.S.G. and F. R.P. Rocha. Talanta. 71: 1507 - 1511. (2007).

22. Ascar, L., I. Ahumada and P. Richter. Chemosphere. 70: 1211-1217. (2008)

23. Massumi A., N. M. Najafi and H. Barzegari. Microchem. J. 72: 93-101. (2002).

24. Myers, R.H. and D.C, Montgomery. Response Surface Methodology: Process and Product Optimization Using Designed Experiments. Wiley. (2002).

25. Savitzky, A. and M.J.E. Golay. Anal. Chem. 36: 1627-1639. (1964).

26. M. I. Toral, J. Rivas, M. Saldías, C. Soto, S. Orellana. J. Chil Chem. Soc. 53 (2) 1543-1547. (2008)

27. C. Soto, D. Contreras, M. I. Toral, L. Basaez and J. Freer. J. Chil Chem. Soc. 54 (2009). 